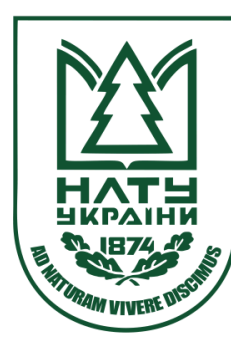

Науковий вісник НлтУ України Scientific Bulletin of UNFU

ISSN 1994-7836 (print)

https://nv.nltu.edu.ua

https://doi.org/10.15421/40280806

Article received 02.10.2018 p.

Article accepted 25.10.2018 p.

Correspondence author

удк 630*165.44:582.746.56

M. M. Huz

mguz@ukr.net

В. Ф. Гевал, М. М. Гузь

Національний лісотехнічний університет Украйни, м. Львів, Украӥна

\title{
ОСОБЛИВОСТІ ГЕТЕРОВЕГЕТАТИВНОГО РОЗМНОЖЕННЯ ГІРКОКАШТАНІВ
}

Досліджено ефективність різних способів щеплення найпоширеніших у Західному регіоні України видів жовто-рожевоквіткового (Aesculus hibrida D. C.), червоноквіткових (Aesculus pavia L. і Aesculus carnea Hayne) та жовтоквіткового (Aesculus octandra Marsh.) гіркокаштанів. Апробовано три способи гетеровегетативного розмноження - "у розщіп", "у боковий розріз" та "окуліровка" для чотирьох видів гіркокаштанів. Підщепами були 8-річні саджанці гіркокаштана кінського звичайного. Прищепами - однорічні пагони із середини крони або вертикальний верхівковий пагін, 3 яких нарізали здорові, зрілі, без пошкоджень живці довжиною 8-10 см. Щеплення проведено у другій декаді квітня у відкритому грунті шкільного відділення декоративного розсадника. За щепленими рослинами виконано агротехнічні та селекційні догляди протягом наступних років вирощування. Встановлено, що найвищою приживлюваністю відзначається спосіб "у бічний розріз" (56,0-80,0 \%) під час щеплень усіх видів гіркокаштанів. Квітувати щеплені рослини почали на другий-третій рік після щеплення, а формувати плоди з повнозернистим доброякісним насінням - на четвертий-п'ятий. Виробнича собівартість одного щепленого 2-річного саджанця гіркокаштанів у відкритому грунті, залежно від виду прищепи, становить 80,5-115,0 грн. Проведені експериментальні щеплення саджанців різних видів гіркокаштанів засвідчили широкі технологічні можливості та значну економічну ефективність гетеровегетативного розмноження різними способами для отримання садивного матеріалу щеплених декоративних червоно- та жовтоквіткових культиварів гіркокаштанів. Застосовані способи щеплення ("у бічний розріз" та "у розщіп") рекомендовано використовувати у промислових обсягах для розмноження особливо декоративних і стійких до негативного впливу абіотичних і біотичних чинників культиварів гіркокаштанів.

Ключові слова: гіркокаштани; гетеровегетативне розмноження; ефективність способів щеплення.

Вступ. Багаторічний досвід культивування різних видів гіркокаштанів у багатьох країнах на різних континентах засвідчив їхню здатність до різних способів вегетативного розмноження як автовегетативного, так i гетеровегетативного. При цьому гетеровегетативне розмноження набуло ширшого практичного застосування під час вирощування садивного матеріалу різних видів гіркокаштанів. Щодо автовегетативного розмноження, то наявні в науковій літературі дані не дають однозначної відповіді про реальність і успішність цього процесу.

Особливого значення використання гетеровегетативного розмноження набуває для отримання культиварів із можливістю збереження властивостей материнських рослин, або за обмежених можливостей насінного розмноження (Bilous, 2003).

Із попередніх робіт авторів цієї публікації відомо, що насінний потенціал гіркокаштанів павія, м'ясо-червоного та восьмитичинкового у Західному регіоні України є обмеженим (Heval \& Huz, 2012; 2013). Ще менші можливості щодо заготівлі насіння із відомих форм дерев цих видів, які взагалі трапляються у насадженнях поодиноко, що не дає змоги сподіватися на можливість ix успішного вирощування насінним способом. Окрім цього, наш досвід насінного вирощування великомірного садивного матеріалу гіркокаштана м'ясо-червоного засвідчив, що до 10-15 \% саджанців цього виду гіркокаштана притаманні квіти білуватого кольору, як наслідок гібридного походження рослини.

Гетеровегетативне розмноження або щеплення - це той спосіб вегетативного розмноження, завдяки якому відбулося розширення асортименту декоративних культиварів із різним кольором квіток, форм крони тощо, які поповнили перелік декоративних особин у скверах, парках та вуличних насадженнях насамперед великих міст (Bilous, 2003; Debryniuk, Kalinin, Huz \& Shablii, 1998; Cherniak, 2004).

Об'єкти дослідження - розмноження саджанців дерев чотирьох видів гіркокаштанів.

Предмет дослідження - методи і засоби гетеровегетативного розмноження гіркокаштанів кінських павія (Aesculus pavia L.), восьмитичинкового (Aesculus octandra Marsh.), гібридного (Aesculus hibrida D. C.) та червоноквіткового або м'ясо-червоного (Aesculus carnea Hayne).

Мета дослідження - встановити ефективність різних способів щеплення найпоширеніших у Західному регіоні України видів жовто-рожевого, червоноквіткових та жовтоквіткового гіркокаштанів.

Протягом тривалого терміну досліджень ми неодноразово проводили спроби гетеровегетативного розмно-

\section{Інформація про авторів:}

Гевал Володимир Федорович, здобувач, кафедра лісових культур і лісової селекції. Email: mguz@ukr.net

Гузь Микола Михайлович, д-р с.-г. наук, професор, завідувач кафедри лісових культур і лісової ceлекції. Email: mguz@ukr.net

Цитування за ДСту: Гевал В. Ф., Гузь М. М. Особливості гетеровегетативного розмноження гіркокаштанів. Науковий вісник Нлту України. 2018, т. 28, № 8. С. 32-36.

Citation APA: Geval, V. F., \& Huz, M. M. (2018). Some features of hetero-vegetative propagation of horse chestnut. Scientific Bulletin of UNFU, 28(8), 32-36. https://doi.org/10.15421/40280806 
ження гіркокаштанів із використанням кількох способів щеплення та живців різного походження. Такі експериментальні щеплення проводили у 2000-2010 рр. на невеликій кількості (10-20 шт.) саджанців кожного виду. У процесі цих досліджень попередньо було визнано малопридатним для гетеровегетативного розмноження гіркокаштанів такий спосіб щеплення, як "окуліровка", та використання як прищепи живців із квітковими бруньками.

"Окуліровка" виявилася найменш ефективним способом щеплення для садивного матеріалу гіркокаштанів м'ясо-червоного, восьмитичинкового і гібридного (приживлюваність щеплених саджанців до 10-15\%). При цьому використання живців із квітковими бруньками за будь-якого способу щеплення теж визнано недоречним. Останнє пов'язане 3 тим, що за успішного щеплення вже у перший рік розвитку щепленої рослини відбувається розвиток квіткової бруньки, прищепа інтенсивно розвивається і завдяки ії значній масі відбувається відламування у місці щеплення.

Набутий попередній досвід був узагальнений і використаний весною 2013 р. для більш масштабного експериментального щеплення чотирьох видів гіркокаштанів на підщепах найпоширенішого в Україні гіркокаштана кінського звичайного (табл. 1). Щеплення проводили у другій декаді квітня у відкритому грунті шкільного відділення декоративного розсадника Ботанічного саду НЛТУ України загальнодержавного значення. Підщепами були 8-річні саджанці гіркокаштана кінського звичайного у шкільному відділенні розсадника. Живці для щеплення брали 3 дерев чотирьох видів гіркокаштанів: павія, м'ясо-червоного, гібридного та восьмитичинкового.

Усього було проведено понад 400 щеплень чотирьох видів гіркокаштанів із використанням трьох способів щеплення. Щеплення проводили на висоті 50-100 см від кореневої шийки підщеп.

Як прищепи ми використовували однорічні пагони iз середини крони або вертикальний верхівковий пагін. Із цих пагонів нарізали здорові, зрілі, без пошкоджень живці довжиною 8-10 см. Під час щеплення ми застосовували спеціальний інвентар: садовий ніж, секатор, обв'язувальний матеріал (поліетиленова стрічка) та садовий вар.

Результати дослідження. На сьогодні більшість дорослих дерев червоно-, а особливо жовтоквіткових культиварів гіркокаштанів у різних типах і видах зелених насаджень заходу України - це щеплені рослини. При цьому як підщепи найчастіше були використані рослини найпоширенішого виду - гіркокаштана кінського звичайного. А для прищеп використовували живці 3 гіркокаштанів із кольоровими квітами павія, м'ясочервоний, рідше - восьмитичинковий. Що стосується способів, то найчастіше було щеплення "у розщіп".

Цікаво відзначити, що у різний час практикували різну висоту місця щеплення. Так у дерев гіркокаштанів, яким на сьогодні 100 і більше років, щеплення проводили за звичай на рівні кореневої шийки або на висоті 5-10 см вище неї (рис. 1). Дерева, які були щеплені 50-70 років тому, відрізняються більш високим місцем щеплення - на висоті до 40-100 см від кореневої шийки (рис. 2). Рослин із вищими підщепами ми не виявили. Аналогічно ми не виявили щеплених дерев гіркокаштанів молодшого віку в регіоні досліджень.
За щепленими рослинами проводили агротехнічні та селекційні догляди. Агротехнічні догляди полягали у проведенні боротьби з бур'янами та розпушуванні грунту ручними знаряддями. Протягом усього терміну вирощування щеплених саджанців за ними щорічно проводили по два хімічні догляди гербіцидом суцільної дії "Чистопол" (третя декада квітня і перша декада вересня) та по два агротехнічні (перша декада липня та перша декада серпня). Під час здійснення цих доглядів звертали особливу увагу на забезпечення збереження щеплених рослин.

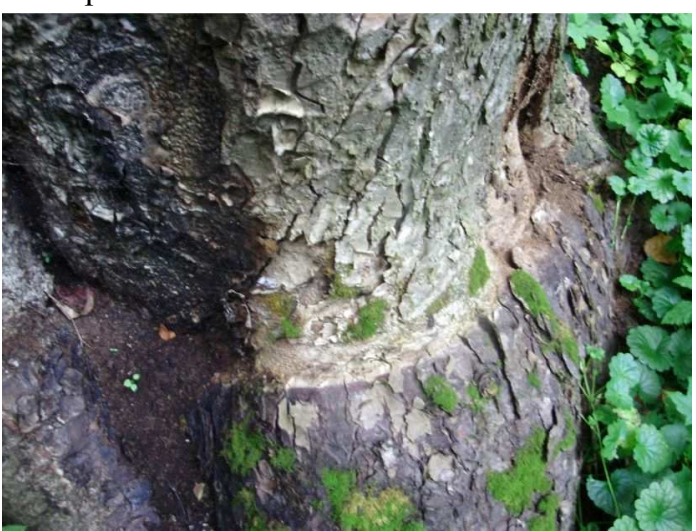

Рис. 1. Щеплення гіркокаштана восьмитичинкового на рівні кореневої шийки зроблено на початку XX ст. (парк смт. Гоща Рівненської обл.)

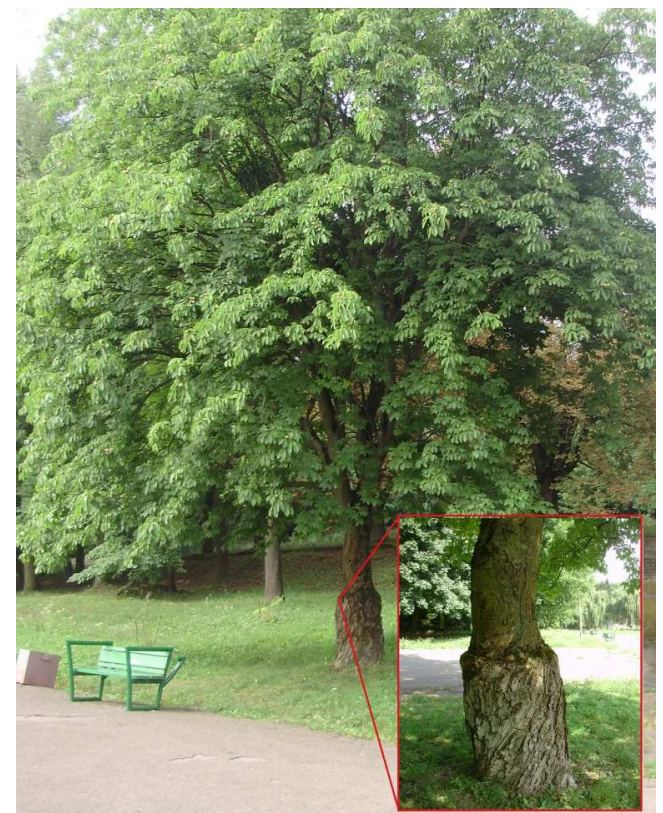

Рис. 2. Приклад щеплення гіркокаштана павія з високим штамбом (парк КІВ ім. Б. Хмельницького, м. Львів)

Проведення селекційного догляду передбачало виконання таких операцій: послаблення і зняття обв'язок, обрізування бокових гілок та розпущених сплячих бруньок нижче місць щеплення на штамбі. У процесі селекційних доглядів також обрізували прищепи з очевидними ознаками відпаду.

Використання способів щеплення, наведених у табл. 1, в аналогічних умовах відкритого грунту свідчить про їхню різну ефективність. Так, під час щеплення усіх видів гірко каштанів, найвищою приживлюваністю відзначається спосіб "у бічний розріз" (56,080,0 \%). За способу щеплення "у розщіп" приживлюваність становила 33,3-63,3 \%. А використана для гіркокаштана павія "окуліровка" підтвердила свою низьку 
ефективність для гетеровегетативного розмноження гіркокаштанів із приживлюваністю 23,3 \%.

Незважаючи на нижчі показники приживлюваності під час щеплення "у розщіп", вважаємо що цей спосіб заслуговує на рекомендацію його для гетеровегетативного розмноження гіркокаштанів, оскільки він найбільш повно забезпечує прямолінійне формування щепленої частини стовбура рослин вже у перший рік без додаткових заходів із формування штамбу. У щеплених рослин усіх видів гіркокаштанів у рік щеплення спостерігали незначний приріст прищеп за висотою у межах 5-12 см. Більш інтенсивним приростом відзначилися щеплені рослини на другий рік після щеплення. Окремі саджанці за другий вегетаційний період після щеплення мали приріст за висотою до 20,5-35,0 cм.

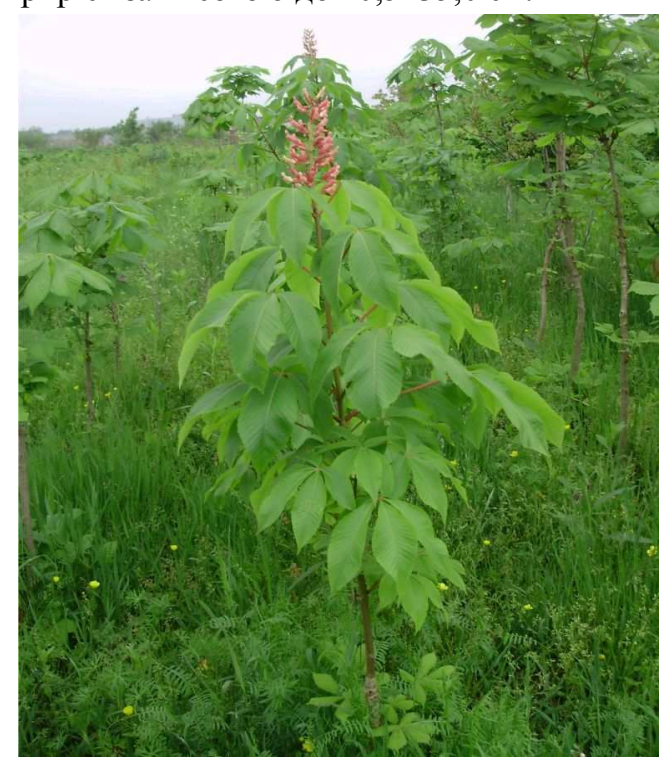

Рис. 3. Квітування трирічного щепленого саджанця гіркокаштана павія

Квітувати щеплені рослини почали на другий-третій рік після щеплення (рис. 3), а формувати плоди з повнозернистим доброякісним насінням - на четвертийп'ятий (рис. 4). Розрахунки собівартості вирощування усереднених дворічних щеплених саджанців гіркокаштанів наведено у табл. 1.

Табл. 1. Результати щеплення саджанців гіркокаштанів різними способами

\begin{tabular}{|c|c|c|c|c|c|}
\hline \multirow{4}{*}{$\begin{array}{l}\text { Дата щеп- } \\
\text { лення, p. }\end{array}$} & \multirow{4}{*}{$\begin{array}{c}\text { Видова назва } \\
\text { прищепи }\end{array}$} & \multirow{4}{*}{$\begin{array}{c}\text { Спосіб } \\
\text { щеплення }\end{array}$} & \multirow{2}{*}{\multicolumn{3}{|c|}{ Кількість щеплень, }} \\
\hline & & & & & \\
\hline & & & \multirow{2}{*}{$\begin{array}{l}\text { всього, } \\
\text { Шт. }\end{array}$} & \multicolumn{2}{|c|}{ успішних } \\
\hline & & & & шт. & $\%$ \\
\hline 10.04 .2013 & Г. павія & $\begin{array}{l}\text { У бічн } \\
\text { розрі }\end{array}$ & 100 & 80 & 80,0 \\
\hline 11.04 .2013 & Г. павія & У розщіп & 30 & 19 & 63,3 \\
\hline 013 & Г. пав & Окуліровка & 30 & 7 & 23,3 \\
\hline 11.04.2013 & $\begin{array}{c}\text { Г. м'ясо-черво- } \\
\text { ний } \\
\end{array}$ & $\begin{array}{c}\text { У бічний } \\
\text { розріз }\end{array}$ & 50 & 30 & 60,0 \\
\hline 12.04 .2013 & $\begin{array}{c}\text { Г. м'ясо-черво- } \\
\text { ний }\end{array}$ & У розщіп & 30 & 12 & 40,0 \\
\hline 12.04.2013 & Г. гібридний & $\begin{array}{c}\text { у бічний } \\
\text { розріз }\end{array}$ & 50 & 32 & 64,0 \\
\hline 12.04 .2013 & Г. гібридний & у розщіп & 30 & 15 & 50,0 \\
\hline 12.04 .2013 & $\begin{array}{l}\text { Г. восьмити- } \\
\text { чинковий }\end{array}$ & $\begin{array}{l}\text { у бічний } \\
\text { розріз }\end{array}$ & 50 & 28 & 56,0 \\
\hline 12.04.2013 & $\begin{array}{l}\text { Г. восьмити- } \\
\text { чинковий }\end{array}$ & у розщіп & 30 & 10 & 33,3 \\
\hline
\end{tabular}

У наведених розрахунках враховано основні види затрат на щеплення 100 шт. рослин 3 урахуванням діючих станом на 01.08.2018 р. тарифних ставок і цін на основні матеріали, вартість проведення агротехнічних та селекційних доглядів за рослинами протягом двох років. Вартість підщеп у цих розрахунках взято як технологічну собівартість вирощування 8-річних саджанців гіркокаштанів у відкритому грунті із насіння власної заготівлі.

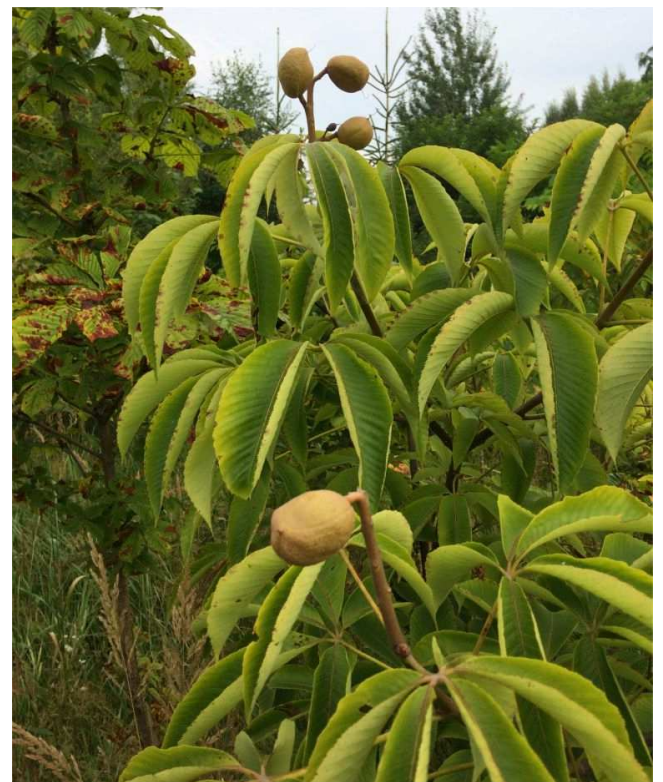

Рис. 4. Плоди у п'ятирічного саджанця гіркокаштана павія

У вартість живців гіркокаштанів включені витрати на оплату робіт із заготівлі та зберіганні живців. Аналіз розрахунків, наведених у табл. 2, свідчить, що незважаючи на достатньо високу виробничу собівартість щеплення рослин гіркокаштанів, воно $є$ економічно обгрунтованим, прибутковим і рентабельним.

Висновки. Проведені експериментальні щеплення саджанців різних видів гіркокаштанів засвідчили широкі технологічні можливості гетеровегетативного розмноження різними способами для отримання садивного матеріалу щеплених декоративних жовто-рожевого, червоно- та жовтоквіткових культиварів гіркокаштанів. Під час щеплення у відкритому грунті найвищий рівень приживлюваності 3 апробованих способів забезпечує щеплення "у бічний розріз", а найменшу - "окуліровка". Застосовані способи щеплення ("у бічний розріз" та "у розщіп") засвідчили їхню високу технологічну та економічну ефективність, тому їх доцільно рекомендувати для використання у промислових обсягах для розмноження особливо декоративних і стійких до негативного впливу абіотичних і біотичних чинників культиварів гіркокаштанів. До таких відносимо передусім декоративні форми гіркокаштанів павія (f. atrosangvinea Kirchn., f. humilis (Lindl.) Mouillef тa f. sublaciniata Wast. (atrapurpurea Spach)) та м'ясо-червоного (var. briotii Bean, var. pendula A. Henry, f. pendula (A.Henry) Rehder тa f. aureo-marginata Hort).

\section{Перелік використаних джерел}

Bilous, V. I. (2003). Lisova selektsiia. Uman: Umanske vydavnychopolihrafichne pidpryiemstvo, 534 p. [In Ukrainian].

Cherniak, V. M. (2004). Kultyvovana dendroflora Volyno-Podillia, perspektyvy yii vykorystannia ta zbahachennia. Ternopil: Publishing TNPU, 264 p. [In Ukrainian].

Debryniuk, Yu. M., Kalinin, M. I., Huz, M. M., \& Shablii, I. V. (1998). Lisove nasinnytstvo. Lviv: Svit, 432 p. [In Ukrainian].

Heval, V. F., \& Huz, M. M. (2012). Suchasnyi stan nasinnoho potentsialu hirkokashtana vosmytychynkovoho u Zakhidnomu rehioni Ukrainy. Stan i bioriznomanittia ekosystem Shatskoho Natsionalno- 
ho pryrodnoho parku: mater. nauk. konf., (pp. 7-10), 6-9 veresnia 2012 r., Shatsk. Lviv: SPOLOM. [In Ukrainian].

Heval, V. F., \& Huz, M. M. (2013). Suchasnyi stan nasinnoho potentsialu chervonokvitkovykh hirkokashtaniv u Zakhidnomu rehioni Ukrainy. Tezy 63-i naukovo- tekhnichnoi konferentsii profesorsko-vykladatskoho skladu, naukovykh pratsivnykiv, doktorantiv ta aspirantiv za pidsumkamy naukovoi diialnosti u 2012 rotsi, (pp. 16-20). Lviv: RVV NLTU Ukrainy. [In Ukrainian].

Табл. 2. Калькулювання виробничої собівартості вирощування 2-річних щеплених саджанців гіркокаштанів у відкритому грунті

\begin{tabular}{|c|c|c|c|c|c|c|c|c|c|c|}
\hline \multirow[b]{2}{*}{ Статті витрат } & \multirow{2}{*}{$\begin{array}{c}\text { Од. } \\
\text { виміру }\end{array}$} & \multirow{2}{*}{$\begin{array}{l}\text { Обсяг } \\
\text { робіт }\end{array}$} & \multicolumn{4}{|c|}{ Види гіркокаштанів } & \multicolumn{4}{|c|}{ Сума витрат за видами гіркокаштанів, грн } \\
\hline & & & \begin{tabular}{|c|} 
восьмити- \\
чинковий \\
\end{tabular} & $\begin{array}{l}\text { гібрид- } \\
\text { ний }\end{array}$ & \begin{tabular}{|c|} 
м'ясо- \\
червоний
\end{tabular} & павія & $\begin{array}{l}\text { восьмити- } \\
\text { чинковий }\end{array}$ & гібридний & \begin{tabular}{|c|} 
м'ясо-чер- \\
воний
\end{tabular} & павія \\
\hline $\begin{array}{l}\text { Вартість 8-річних саджанців } \\
\text { підщеп }\end{array}$ & шт. & 100 & 21,58 & 21,58 & 21,58 & 21,58 & \multicolumn{4}{|c|}{21,58} \\
\hline $\begin{array}{l}\text { Приживлюваність щеплених } \\
\text { саджанців }\end{array}$ & $\%$ & & 56,0 & 64,0 & 60,0 & 80,0 & 56,0 & 64,0 & 60,0 & 80,0 \\
\hline Основна заробітна плата & шт. & 100 & & & & & \multicolumn{4}{|c|}{2046,76} \\
\hline Додаткова заробітна плата & Шт. & 100 & & & & & \multicolumn{4}{|c|}{511,76} \\
\hline $\begin{array}{l}\text { Відрахування на соціальні } \\
\text { потреби }(38,04 \%)\end{array}$ & шт. & 100 & & & & & \multicolumn{4}{|c|}{973,22} \\
\hline $\begin{array}{l}\text { Інші витрати (витрати на ос- } \\
\text { новні матеріали) }\end{array}$ & шт. & 100 & & & & & \multicolumn{4}{|c|}{51,10} \\
\hline $\begin{array}{l}\text { Технологічна собівартість } \\
\text { (усього) }\end{array}$ & шт. & 100 & & & & & \multicolumn{4}{|c|}{3568,85} \\
\hline $\begin{array}{l}\text { Загальновиробничі витрати } \\
(43,9 \%)\end{array}$ & $\mathrm{M}^{2}$ & 320 & & & & & \multicolumn{4}{|c|}{1566,73} \\
\hline $\begin{array}{l}\text { Адміністративні витрати } \\
(36,3 \%)\end{array}$ & шт. & 100 & & & & & \multicolumn{4}{|c|}{1306,20} \\
\hline $\begin{array}{l}\text { Виробнича собівартість од- } \\
\text { ного щепленого саджанця }\end{array}$ & $\begin{array}{l}\text { грн/ } \\
\text { Шт. }\end{array}$ & 1 & & & & & 115,03 & 100,65 & 107,35 & 80,52 \\
\hline $\begin{array}{l}\text { Реалізаційна ціна одного щеп- } \\
\text { леного саджанця з ПДВ }\end{array}$ & $\begin{array}{l}\text { грн/ } \\
\text { шт. }\end{array}$ & 1 & & & & & \multicolumn{4}{|c|}{250,00} \\
\hline Прибуток & грн & & & & & & 134,97 & 149,35 & 142,65 & 169,48 \\
\hline Рентабельність & $\%$ & & & & & & 117,33 & 148,39 & 132,88 & 210,48 \\
\hline
\end{tabular}

Примітка: * Розрахунок проведено на 100 шт. щеп гіркокаштанів.

В. Ф. Гевал, Н. М. Гузь

Национальный лесотехнический университет Украины, г. Львов, Украина

\section{ОСОБЕННОСТИ ГЕТЕРОВЕГЕТАТИВНОГО РАЗМНОЖЕНИЯ КОНСКИХ КАШТАНОВ}

Исследована эффективность различных способов прививки наиболее распространенных в Западном регионе Украины видов конских каштанов - желто-розовоцветного (Aesculus hibrida D. C.), красноцветных (Aesculus pavia L. и Aesculus carnea Hayne) и желтоцветного (Aesculus octandra Marsh.). Апробированы три способа гетеровегетативного размножения - " в расщеп", " в боковой зарез" и "окулировка" на четырех видах конских каштанов. В качестве подвоя использованы 8-летние саженцы конского каштана обыкновенного. Привоем служили однолетние побеги из средней части кроны или вертикальные верхушечные побеги, из которых нарезали созревшие без повреждений черенки длиной 8-10 см. Прививки проведены во второй декаде апреля в открытом грунте школьного отделения декоративного питомника. За привитыми растениями проведены агротехнические и селекционные уходы в течении следующих лет выращивания. Установлено, что наивысшей приживаемостью отличается способ "в боковой зарез" (56,0-80,0 \%) при использовании для прививки всех видов конских каштанов. Привитые растения начали цветение на второй-третий годы после прививки, а формировать плоды из полнозернистыми доброкачественными семенами - на четвертый-пятый. Производственная себестоимость одного привитого 2-летнего саженца конских каштанов, в зависимости от вида, в открытом грунте составляет 80,5-115,0 грн. Проведенные экспериментальные прививки саженцев различных видов конских каштанов свидетельствуют о значительных технологических возможностях и существенной экономической эффективности гетеровегетативного размножения разными способами с целью получения посадочного материала привитых декоративных культиваров конских каштанов. Использованные способы прививки ("в боковой зарез" и "в расщеп") рекомендованы для использования в промышленных объемах для размножения особенно декоративных и стойких к негативному влиянию абиотических и биотических факторов культиваров конских каштанов.

Ключевые слова: конские каштаны; гетеровегетативное размножение; эффективность способов прививки.

V. F. Geval, M. M. Huz

Ukrainian National Forestry University, Lviv Ukraine

\section{SOME FEATURES OF HETERO-VEGETATIVE PROPAGATION OF HORSE CHESTNUT}

Hetero-vegetative propagation, or grafting, is a method of vegetative propagation that enables the reproduction of decorative cultivars with various colours of flowers, crowns, etc. The authors have studied the effectiveness of different methods of grafting of the most common in the western region of Ukraine types of yellow-pink horse chestnut (Aesculus hybrida D.C.), red horse chestnut (Aesculus pavia L. and Aesculus carnea Hayne), and yellow buckeye (Aesculus octandra Marsh.). In the course of reseach we have tested three methods of hetero-vegetative propagation of the four types of horse chestnuts, namely, "in split", "in lateral section", and "oculating". Eight-year-old seedlings of horse chestnut served as rootstocks. One-year-old horse chestnut shoots from the middle of the crown or a vertical ridge, from which the healthy, well-grown, $8-10 \mathrm{~cm}$ long cuttings without damage were used as grafts. Grafting was carried out in the second decade of April in the open-air of the school branch of the decorative nursery. In total, more than 400 gratings of four types of horse chestnuts were performed using three grafting types. Grafting was carried out at a height of 80 $100 \mathrm{~cm}$ from the root cervix of the rootstock. Grafted plants were provided with agro-technical and selective care. Agro-technical ca- 
re consisted of combating weeds and loosening the soil with hand-held implements. Throughout the entire period of growth of grafted seedlings, two chemical treatments with the Chistopol herbicide (the third decade of April and the first decade of September) and two agro-technical ones (the first decade of July and the first decade of August) were carried out each year. Special attention was paid to ensuring the preservation of grafted plants when nursing. Flowering of grafted plants is found to start in the second or third year after grafting, and to form fruits with full-grained high quality seeds - in the fourth or fifth year. Experimental grafting of seedlings of different species of horse chestnut has shown the wide technological possibilities of hetero-vegetative propagation by various methods for receiving seed material of grafted decorative red and yellow-flowered cultivars of horse chestnuts. When grafting in open ground, "in the lateral section" grafting provided the highest level of survival of all tested methods, and "oculating" showed the lowest level respectively. Thus, we would recommend "in split" and "in lateral section" methods of grafting as those having demonstrated a high technological and economic efficiency in order to use in industrial volumes for the propagation of especially decorative and resistant to the negative effects of the abiotic and biotic factors of the cultivars of horse chestnut.

Keywords: horse chestnut; hetero-vegetative propagation; efficiency of grafting methods. 